\title{
ЗМІСТ ПРОФЕСІЙНОЇ ПІДГОТОВКИ ФАХІВЦІВ СФЕРИ ОБСЛУГОВУВАННЯ
}

\author{
Лариса Савченко \\ доктор педагогічних наук, професор \\ завідувачка кафедри педагогіки \\ та методики технологічної освіти \\ Криворізького державного педагогічного університету \\ м. Кривий Ріг, Україна \\ ORCID ID 0000-0002-4246-3228 \\ larisasavcenko506@gmail.com
}

\begin{abstract}
Анотація. У статті розглянуто проблему змісту професійної підготовки фахівців сфери обслуговування. Зміст професійної освіти має ознаку багатофункціональності, умотивовану чисельністю навчальних спеціальностей i наукових напрямів, за якими відбувається підготовка фахівців. Професійна підготовка - це процес, у ході якого осмислюють, оптимізують навчання, дбають про об'єктивний аналіз освітніх результатів, що забезпечують можливість успішної роботи з певної професії; при вивченні педагогічних і спеціальних дисциплін. Повноцінна спеціальна підготовка майбутніх фахівців повинна забезпечити формування системи практичних знань, умінь та навичок із технології організації готельного і ресторанного господарства, сервіс у ресторанному та готельному господарстві, професійний етикет, інженерна та комп'ютерна графіка. Обсяг навчальної інформації за вищезазначеними навчальними дисциплінами великий і має тенденцію до зменшення. Вища професійна освіта - найважливіший соціально-державний інститут, що виконує функцію підготовки молодого покоління до розв'язання в майбутньому професійних завдань у певній сфері діяльності й передбачає високий рівень сформованості у випускників різних умінь і навичок, а також здатності постійно їх удосконалювати.
\end{abstract}

Ключові слова: зміст освіти; професійна освіта; сфера обслуговування; рестораноготельна справа.

Постановка та обгрунтування актуальності проблеми Нині формується новий образ гуманістичної педагогічної науки, що окреслює напрям підготовки кадрів і розвиток особистості на всіх ступенях освіти.

Вища освіта має на меті підготувати людину до професійної діяльності й активної участі в громадському житті. Представник професії повинен відповідати низці вимог: а) до якостей особистості, яка живе в конкретноісторичний період; б) до рівня загального розвитку; в) до рівня спеціальнопрофесійних знань і вмінь (вимоги індивідуальні для різних професій). Підготовку майбутніх фахівців сфери обслуговування аналізують відповідно до вимог особистості й професійної діяльності.

Становлення нової професійної української освіти потребує викладача нової формації. Відтак з огляду на сучасні виклики ринку праці, глобалізаційні 
процеси вважаємо розробку Концепції розвитку професійної освіти вчасною і важливою. У сучасних умовах реформування економіки, становлення нових економічних відносин в Україні значно розширюється коло вимог, що висуваються до кваліфікації спеціаліста, який працює у сфері обслуговування.

Аналіз останніх досліджень i публікацій. Проблеми професійної підготовки спеціалістів для сфери обслуговування знайшли відображення в наукових роботах таких авторів: В. Зубков, Р. Каверина, А. Михайлов, Б. Ройзман, Р. Чернишева, Г. Хорошавіна та ін. Питання професійної культури працівника сфери обслуговування досліджується низкою вчених: Г. Аванесовою, В. Велединським, В. Далем, Б. Ройзман, В. Зубковою, О. Лойко, Е. Климовою, Н. Левитовим, А. Таушкановою, А. Опалєвим, Е. Уткіним, В. Федцовим, В. Ященко.

Формулювання цілей статті. Мета статі - розглянути проблеми змісту професійної підготовки фахівців сфери обслуговування. Зміст професійної освіти має ознаку багатофункціональності, умотивовану чисельністю навчальних спеціальностей $\mathrm{i}$ наукових напрямів, за якими відбувається підготовка фахівців. Задачі статті: 1) визначити зміст професійної освіти; 2) провести анкетування й опитування студентів для визначення пізнавального інтересу до професійної освіти (сфери обслуговування); 3) запропонувати інформаційно-комунікаційні технології в підготовці майбутніх фахівців сфери обслуговування.

Методика дослідження полягає в аналізі складання студентами I - IV курсів у кількості 67 осіб заліків та іспитів, регулярності виконання завдань із дисциплін професійного спрямування. Використовувались методи дослідження, такі як: спостереження, бесіди для з'ясування рівня стурбованості студентів у подальшій професійній діяльності, що позначається на якості навчальної діяльності.

Виклад основного матеріалу. У наш час сфера обслуговування є однією 3 найперспективніших галузей економіки. Вона охоплює широке поле діяльності від торгівлі та транспорту до фінансування та страхування. Готелі та ресторани, салони краси, навчальні та спортивні заклади, туристичні фірми, радіо- та телестанції, консультаційні фірми, медичні заклади, музеї, театри, кінотеатри, магазини та супермаркети належать до сфери послуг.

Вища професійна освіта - найважливіший соціально-державний інститут, що виконує функцію підготовки молодого покоління до розв'язання в майбутньому професійних завдань у певній сфері діяльності й передбачає високий рівень сформованості у випускників різних умінь і навичок, а також здатності постійно їх удосконалювати.

Професіоналізм педагога: теоретичні й методичні аспекти. - Вип. 11. - Слов’янськ, 2019. 
Унаслідок аналізу навчальних планів підсумовано, що зміст, обсяг навчальної інформації у вищих педагогічних навчальних закладах різний. Навчальні плани в Україні поділяють на типові й індивідуальні. Типові навчальні плани однакові для всіх однотипних освітніх закладів. Окремі провідні навчальні закладі, що мають солідний досвід організації навчання студентів, великі наукові школи розробляють власні навчальні плани, де відображено сталі традиції освітньої установи, особливості наукової роботи.

Навчальний план - основний нормативний документ (стандарт) вищого навчального закладу, що складають на підставі освітньо-професійної програми і структурно-логічної схеми підготовки фахівців. Згідно з планом організовують навчальну діяльність, описуючи графік процесу навчання; перелік та обсяг навчальних дисциплін; послідовність їхнього опанування; конкретні форми проведення занять (лекції, семінари, лабораторні тощо) та їхній обсяг; форми проведення підсумкового контролю (екзамен, залік, диференційований залік); порядок проведення практики, іï види; обсяг часу, передбаченого для самостійної роботи студентів; кількість курсових робіт, які виконує студент за період навчання; зміст і форми державної атестації (Кузьмінський, 2005).

Конкретне наповнення змісту кожного навчального предмета в освітньому закладі - справа фахівців із цих предметів. Завдання дидактики - сформулювати принципи, якими потрібно керуватися в процесі відбору змісту. Основна соціальна функція освіти - передання досвіду, накопиченого попередніми поколіннями людей у формі матеріальної й духовної культури. До змісту освіти потрібно включати всі елементи культури:

1) систему знань про природу, суспільство, мислення, способи діяльності (функції цього елемента: формування картини світу, методологічних підходів до пізнавальної й практичної діяльності);

2) систему інтелектуальних і практичних навичок і вмінь, що дає змогу новим поколінням відтворювати культуру та зберігати іiі;

3) досвід творчої діяльності (засвоєння цього елемента вможливлює подальший розвиток культури);

4) систему норм ставлення до світу, одне до одного, що зумовлює моральні стимули, естетичну потребу, емоційну забарвленість, мотиви діяльності тощо, тобто всі вияви ставлення до діяльності та її продуктів.

Постає проблема відбору змісту дисциплін науки для включення його до навчальної дисципліни, бо кількість і глибина наукових знань суттєво перебільшують обсяг, який можуть засвоїти студенти. Крім того, зміст навчального предмета відрізняється від змісту науки через безперервний прогрес наукового знання.

() ДВНЗ «Донбаський державний педагогічний університет» 
Зміст освіти - структура, зміст та обсяг навчальної інформації, засвоєння якої дає особі змогу здобути вищу освіту й певну кваліфікацію. Зміст навчання поділений на нормативну частину (обов'язкова для засвоєння, сформована відповідно до вимог освітньо-кваліфікаційної характеристики, має змістові модулі із зазначенням їхнього обсягу й рівня засвоєння, а також форм державної атестації) і вибіркову частину (рекомендована для засвоєння, диференційована за змістовими модулями з описом їхнього обсягу та форм атестації, призначена для задоволення потреб і можливостей особистості, регіональних потреб у фахівцях певної спеціальності та спеціалізації з огляду на досягнення наукових шкіл і вищих навчальних закладів).

Модернізація освіти передбачає зміну мети, скорочення обсягу обов'язкового змісту, модифікацію методів і технологій засвоєння змісту на всіх рівнях навчання, індивідуалізацію процесу навчання, можливість варіативних систем освіти. Відповідно до цього предметом змін будуть стандарти, програми, навчальні плани. Аналіз навчальних планів довів, що зміст освіти різний не лише в різних закладах (університетах і коледжах), але й у межах одного навчального закладу, навіть за однією спеціальністю.

Сучасний зміст освіти - багатокомпонентний. Він має включати не лише знання, а й способи практичної діяльності, творчий досвід, ціннісні орієнтації особистості. Отже, зміст освіти у вищій школі - це система знань, умінь, навичок, якими мають володіти ті, хто навчається в певний період для здобуття професії на рівні фахівця вищої кваліфікації. Методологічними засадами підготовки майбутніх фахівців слугує в теоретичному зрізі гносеологічний, гуманістичний підхід, безперервність, цілісність, наступність; у практичному вимірі діяльнісний, аксіологічний, системний, компетентнісний підходи.

Важливим показником успішності експериментальної роботи також $\epsilon$ підвищення рівня відповідальності й наполегливості студентів у навчанні. Так, в експериментальних групах досягнуто майже стовідсоткової вчасності складання заліків та іспитів, регулярності виконання завдань.

Сформованість кількісних показників розвитку професійного інтересу студентів експериментальних і контрольних груп представлено в табл. 1

Згідно $з$ табл. 1 в експериментальній групі зафіксовано значний приріст кількості студентів із високим рівнем професійного інтересу, причому разом 3 адаптацією студентів до кредитно-модульної системи навчання забезпечено педагогічно доцільне використання комп'ютерних засобів контролю. Це дає підстави стверджувати, що для студентів закладу вищої освіти особливе значення має продуктивна взаємодія в процесі використання комп'ютерних засобів контролю.

Професіоналізм педагога: теоретичні й методичні аспекти. - Вип. 11. - Слов'янськ, 2019. 


\section{Динаміка кількісних показників професійного інтересу студентів експериментальних і контрольних груп (у \%)}

\begin{tabular}{|c|c|c|c|c|c|c|}
\hline \multirow[b]{2}{*}{$\begin{array}{l}\text { Рівень } \\
\text { професійного } \\
\text { інтересу }\end{array}$} & \multicolumn{3}{|c|}{ Експериментальна група } & \multicolumn{3}{|c|}{ Контрольна група } \\
\hline & 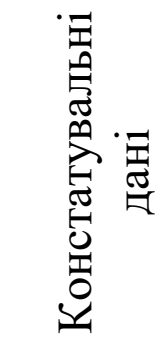 & 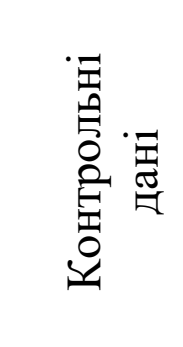 & . & 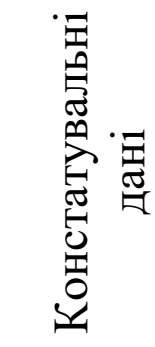 & 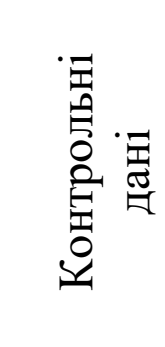 & . \\
\hline Низький & 14,6 & 6,2 & $-8,4$ & 19,2 & 10,1 & $-9,1$ \\
\hline Середній & 66,9 & 30,3 & $-36,6$ & 59,8 & 53,8 & $-6,0$ \\
\hline Високий & 18,5 & 63,5 & $+45,0$ & 21,0 & 36,1 & $+15,1$ \\
\hline
\end{tabular}

У ході експериментальної роботи в студентів експериментальних груп, порівняно з контрольними, констатовано більш виражене прагнення досягти успіху в навчально-пізнавальній діяльності. Так, випадків, коли студенти експериментальних груп намагалися покращити свій рейтинговий бал, зафіксовано майже в 2,5 рази більше, ніж у контрольних групах.

У процесі педагогічного експерименту досліджено вплив окреслених умов ефективної організації контролю навчальної діяльності студентів на рівень стурбованості у подальшій професійній діяльності, як однієї з важливих, на наш погляд, характеристик особистості, що позначається на якості навчальнопізнавальної діяльності в будь-якому віці. У сучасній педагогіці вищої школи порушеному питанню бракує дослідницької уваги. Проблема згадана лише в студіях, що стосуються школярів (О. Газман, Т. Дейниченко, 3. Шилкунова та ін.). Проте науковий пошук переконує в необхідності врахування ступеня стурбованості студентів у процесі навчання й особливо під час проведення контрольних заходів.

Динаміку рівнів стурбованості студентів майбутньою професійною діяльністю у сфері обслуговування експериментальних і контрольних груп представлено в табл. 2.

Відомості, подані в таблиці 2, демонструють, що забезпечення досліджуваних умов позитивно вплинуло на рівень стурбованості студентів експериментальних груп, при цьому найбільш суттєво знизилися показники стурбованості майбутньою професійною діяльністю у сфері обслуговування за рівнем «високий». 


\section{Динаміка рівнів стурбованості студентів у ході оцінювання відповідей в експериментальних і контрольних групах (у \%)}

\begin{tabular}{|c|c|c|c|c|c|c|}
\hline \multirow[b]{2}{*}{$\begin{array}{l}\text { Рівень } \\
\text { стурбованості } \\
\text { студентів }\end{array}$} & \multicolumn{3}{|c|}{ Експериментальна група } & \multicolumn{3}{|c|}{ Контрольна група } \\
\hline & 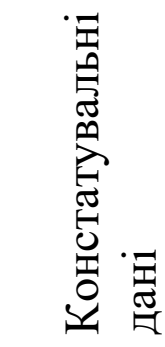 & 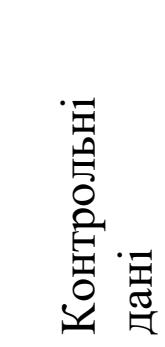 & 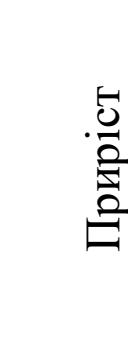 & 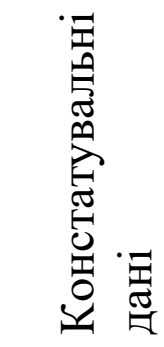 & 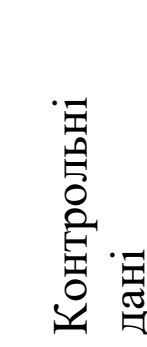 & 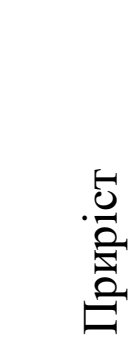 \\
\hline Нормальний & 59,3 & 69,1 & $+9,8$ & 58,7 & 62,4 & $+3,7$ \\
\hline Надспокійний & 17,9 & 21,1 & $+3,2$ & 27,5 & 25,7 & $-1,8$ \\
\hline Високий & 22,8 & 9,8 & -13 & 13,8 & 11,9 & $-1,9$ \\
\hline
\end{tabular}

Зазначимо, що в експериментальних групах зафіксовано приріст студентів, рівень стурбованості яких схарактеризований як «нормальний» $(9,8 \%)$. Це можна пояснити тим, що в такому випадку студенти мали змогу обирати форми роботи та самоконтролю відповідно до індивідуальних особливостей (інтересів, рис характеру тощо) і реальних навчальних можливостей. Водночас отримані дані засвідчують, що в контрольних групах кількість студентів із нормальним рівнем стурбованості також зросла, але ці показники виявилися значно меншими.

Аналізуючи зміни, що відбуваються сьогодні в суспільстві, важливо визначити пріоритетні прояви професійної освіти: направлення використання комп'ютерної графіки, професійна мобільність, інформаційно-комунікативні технології тощо.

Під час вивчення дисципліни «Сервіс у ресторанному та готельному господарстві» у студентів формуються графічні вміння, навички, а також у ході діалогу вони навчаються критично мислити, розв'язувати складні проблеми на основі аналізу обставин і відповідної інформації, зважувати альтернативні думки, приймати продумані рішення, брати участь у дискусіях, спілкуватися 3 іншими людьми. На заняттях інформаційно-комунікативні технології, мультимедійні засоби.

Впровадження інформаційно-комунікаційних технологій у сучасну освіту суттєво прискорює передавання знань і накопиченого технологічного та соціального досвіду людства не лише від покоління до покоління, а й від однієї людини до іншої.

Професіоналізм педагога: теоретичні й методичні аспекти. - Вип. 11. - Слов'янськ, 2019. 
Мультимедійні програмні засоби дозволяють учителю поєднувати текстову, графічну, анімаційну, відео- i звукову інформацію. Одночасне використання кількох каналів сприйняття навчальної інформації дозволяє підвищити рівень засвоєння навчального матеріалу. Мультимедійні програмні засоби доцільно використовувати для імітації складних реальних процесів, ситуацій, візуалізації абстрактної інформації за рахунок динамічного представлення процесів, демонстрації фрагментів передач, фільмів, віртуальних екскурсій тощо.

Пропонуються завдання: ознайомитись із поняттями: «кондитерський виріб», «український кондитерський виріб»; розглянути українські кондитерські, їхню рецептуру та історію виникнення; визначити та проаналізувати використання мотивів українських кондитерських виробі в роботах відомих кондитерів; розробити рецепт та створити макет кондитерського виробу за сполученням декількох народних кондитерських виробів різних країн світу (український мотив обов'язковий!).

Звітна документація: за результатами проходження вебквесту студент(ка) оформлює творчий проєкт та мультимедійну презентацію до нього. Створює власний вебсайт згідно з темою свого проєкту (завдання).

Створення фотосету «Український ресторан». Фотосет (англ. Photoset) сленгове слово, яке $\epsilon$ похідним від «photo» - фото i «set» - набір. Іншими словами, фотосет - це підбір фотографій, зазвичай зроблених у межах однієї фотосесії.

Завдання для фотосету: сфотографувати ресторани в українському (етно) стилі у вашому місті; розглянути фотографії ресторанів різних регіонів України (дизайн інтер'єру, оформлення святкового столу, фотозони ресторану); проаналізувати відмінність ресторанів в етнос стилі та визначити преваги i недоліки; показати оформлення меню та уніформи офіціантів, шеф-повара; оформлення основних страв; представити свій проєкт сучасного етноресторану.

Вважаємо доцільним вивчати окремі сторони професійної компетентності фахівця, серед яких етична має переважне значення, бо передусім моральні цінності й установки визначають мету, стратегію і тактику дії.

При вивчені дисципліни «Професійний етикет» у процесі роботи використовували демонстрацію різних прийомів під час сервірування столу: слайди, плакати, відеофільми, таблиці, інструкційні та технологічні картки, спеціальну літературу. Демонстрували особливості сервірування столів у ресторанах, їдальнях, кафе, закусочних, студентам пропонувались завдання: а) де використовують скатертини? Які? б) покажіть, де стоять прибори для спецій; в) намалюйте (найдіть) у мережі Інтернет особливості покриття столу 
скатертинами (багатошаровість, колір, текстура). Сервірування посудом, завдання: а) сервірування до сніданку; б) сервірування до обіду; в) особливості сервірування посудом до вечері; г) святковий стіл.

\section{Висновок та перспективи подальших розвідок у цьому напрямі.} Професійна підготовка - це процес, у ході якого осмислюють, оптимізують навчання, дбають про об'єктивний аналіз освітніх результатів, що забезпечують можливість успішної роботи 3 певної професії; при вивченні педагогічних і спеціальних дисциплін. Повноцінна спеціальна підготовка майбутніх фахівців повинна забезпечити формування системи практичних знань, умінь i навичок із технології організації готельного та ресторанного господарства, сервіс у ресторанному та готельному господарстві, професійний етикет, інженерна та комп'ютерна графіка. Обсяг навчальної інформації за вищезазначеними навчальними дисциплінами великий і має тенденцію до зменшення.

Вища професійна освіта - найважливіший соціально-державний інститут, що виконує функцію підготовки молодого покоління до розв'язання в майбутньому професійних завдань у певній сфері діяльності й передбачає високий рівень сформованості у випускників різних умінь і навичок, а також здатності постійно їх удосконалювати. Зміст освіти $€$ засобом трансляції культури, оволодіваючи якою людина не лише адаптується до умов постійно мінливого суспільства, але й стає активною. Молодь - найбільш чутлива категорія населення до процесів трансформації суспільства. Спостереження та спілкування зі студентами дає підстави дійти висновку, що більшість із них зорієнтована на те, щоб отримати якісну освіту, досягти матеріального добробуту, кар'єрного зростання у своїй професії. Подальшу свою роботу вбачаємо в розробці творчих проєктів зі сфери обслуговування, які стосуються готельно-ресторанної справи.

\section{СПИСОК ВИКОРИСТАНИХ ДЖЕРЕЛ}

1. Бех І. Д. (2005). Принципи сучасної освіти. Педагогіка і психологія, 4, 5-27.

2. Кремень В. Г. (2006). Якісна освіта: сучасні вимоги. Педагогіка і психологія, 4, $5-17$.

3. Кузьмінський А. І. (2005). Педагогіка вищої школи. Київ, Україна: Знання.

4. Іозіс І. В. (2017). Основні складові формування професійної культури у педагогічній теорії. Науковий вісник Миколаївського наиіонального університету імені В. О. Сухомлинського, 4 (59), 211-217. Миколаїв: МНУ імені В.О. Сухомлинського.

5. Savchenko L., Savchenko K., Marchenko A. \& Pylnik R. (2018). Innovative technologies of pedagogical diagnostics as a means of improving the quality of future specialists' education, 49, 20. 
Зміст професійної підготовки фахівців сфери обслуговування

\title{
THE CONTENT OF VOCATIONAL TRAINING OF THE SPECIALISTS IN THE SERVICE FIELD
}

\author{
Larysa Savchenko \\ Doctor of Pedagogical Sciences, Professor Head of the Department of \\ Pedagogy and Methodology of Technological Education \\ Krvyi Rih State Pedagogical University \\ Kryvyi Rih, Ukraine \\ ORCID 0000-0002-4246-3228 \\ larisasavcenko506@gmail.com
}

\begin{abstract}
The article deals with the issue of the content of vocational training of service professionals. The content of vocational education has a sign of multifunctionality, motivated by the number of educational specialties and scientific fields according to which the training of specialists is realized. Vocational training is a process in which they reflect on, optimize their learning, and take care of an objective analysis of educational outcomes that give them an opportunity to work successfully in a particular profession; in the study of pedagogical and special disciplines. A fullfledged special training of future specialists should ensure the formation of a system of practical knowledge, skills, as well as knowledge in the technology of hotel and restaurant management, service in the restaurant and hotel industry, professional etiquette, engineering and computer graphics. The amount of educational information in the above courses is large and tends to decrease.

Higher vocational education is the most important social-state institute, which performs the function of preparing the younger generation for future professional tasks in a certain field of activity and implies a high level of graduation of different skills and abilities, as well as the ability to constantly improve them. The content of education is a means of broadcasting culture, in which a person not only adapts to the conditions of a constantly changing society, but also becomes active. Youth is the most sensitive category of the population to the processes of social transformation. The observation and communication with students leads to the conclusion that most of them are focused on getting a quality education, achieving material well-being and career advancement in their profession. We see the prospective research in the development of creative service projects related to the hotel and restaurant business.
\end{abstract}

Key words: content of education; vocational education; service sector, restaurant and hotel business.

\section{REFERENCES}

1. Bekh, I. D. (2005). Principles of modern education. Pedahohika i psykholohiia, 4, 5-27.

2. Flint, V. G. (2006). Quality education: current requirements. Pedahohika i psykholohiia, $4,5-17$.

3. Kuzminskyi, A. I. (2005). Pedagogy of high school. Kiev, Ukraine: Znannia.

4. Iosis, I. V. (2017). The main components of the formation of professional culture in pedagogical theory. Naukovyi visnyk Mykolaivskoho Natsionalnoho Universytetu im. V. A. Sukhomlynskoho, 4(59), 211-217. Mykolaiv: un-t im. Sukhomlynskoho.

5. Savchenko, L., Savchenko, K., Marchenko, A. \& Pylnik, R. (2018). Innovative technologies of pedagogical diagnostics as a means of improving the quality of future specialists' education, 49, 20. Espacios (ISSN07981015-Venezuela-Scopus). Retrieved from http://www.revistaespacios.com/a18v39n49/18394920.html

Матеріали надійшли до редакції 08.11.2019 р. 